\title{
Experiential Marketing Strategy Application with Case Study on a Unique Traditional Market in Purworejo, Indonesia
}

\author{
Titin kowati \\ University of Uhammadiyah Purworejo \\ Purworejo, Indonesia \\ titinekowati03@gmail.com
}

\begin{abstract}
Experiential marketing is an effort used by companies or marketers to package products so that they are able to offer emotional experiences to touch the hearts and feelings of consumers. This study aims to analyze the application of experiential marketing strategies in the traditional unique markets of Purworejo, namely Pasar Inis, Creative Market Monggo Mampir, and Pasar Menoreh. The researcher used a qualitative design more specifically, namely a case study design. The data obtained in this case study were analyzed by means of relying on theoretical propositions, namely basing the data and information obtained on theories related to experiential marketing strategies. The results showed that the three traditional unique markets in Purworejo, namely Inis Market, Monggo Mampir Creative Market, and Menoreh Market, have applied experiential marketing strategies to attract and retain customers. All aspects of experiential marketing, namely sense, feel, think, act, and relate have been applied by these markets to provide a pleasant experience and create impressions that touch the emotional side of market visitors.
\end{abstract}

Keywords: Experiential marketing, case study, traditional unique market

\section{INTRODUCTION}

Currently the market is not only a meeting place for sellers and buyers, but has developed into a place that can provide added value to the products offered. For example, a market that can be used as a place for recreation or tourism which can also exist on social media for meet the needs of people who do not want to fall behind the trend. The added value that the company provides to consumers will make consumers have an unforgettable experience (experience memorable) which can attract repurchase of a product.

One of the concepts to create customer satisfaction and repurchase interest is experiential marketing, which is a marketing concept that aims to form loyal consumers through the touch of consumer emotions and provide a positive feeling for the products and services offered (Kartajaya, 2010: 44).

Experiential marketing in the company makes added value (value added) to customers which can create satisfaction and satisfaction, which can be made buying interest again. Araci, et al (2017) explain that the dimensions that make up experiential marketing will be created in the customer which will initially increase customer satisfaction and the customer will intend to behave positively, namely the intention to repurchase (repurchase intention). Meanwhile, according to Hyunjin (2013), consumer satisfaction shows a positive direction between experiential marketing and remarketing intentions. The creation of experiences by using experiential marketing to visitors for perceived services can create a good impression from visitors that make visitors feel satisfied, so that visitors will be interested in making repeat visits.

Research by Araci et.al. (2017) shows that experiential marketing has a positive effect on consumer satisfaction, experiential marketing has a positive effect on consumer repurchase intentions, and satisfaction mediates the effect of experiential marketing on consumer repurchase intentions.

Research by Hyunjin (2013) shows that experiential marketing has a positive effect on consumer satisfaction, experiential marketing also has a positive effect on repurchase intention, and satisfaction mediates the effect of experiential marketing on consumer repurchase intentions.

Research by Nigam (2012) shows that experiential marketing is an important driver for building consumer repurchase interest. If the consumer has an unforgettable experience with the company, the consumer's repurchase interest will be high and vice versa if the consumer does not have a good experience with the company, the consumer's repurchase interest will be low.

In this research, researchers analyzed experiential marketing strategies in traditional unique markets in Purworejo with a qualitative design, more specifically a case study design. The novelty of this research is that researchers do not only look at the influence between variables, but explore the application of experiential marketing strategies in several unique traditional markets. In addition, using a case study design, researchers can take pictures of the phenomena that occur in the research object related to the application of experiential marketing strategies.

The researcher took the object of research on the unique traditional markets in Purworejo, namely Inis Market, Monggo Mampir Creative Market, and Menoreh Market because the traditional markets that are packed with unique and contemporary concepts are very attractive to current visitors. Digital or instragramable 
tourist destinations are currently being targeted by the public, especially the millennial generation who really like selfies. The government did not want to miss this golden opportunity, in the end a number of traditional markets were created which were packaged in the present. The specialty of this digital destination is that it raises the traditional side that is able to make longing for the local wisdom of the area of origin and regional culture to be preserved. These markets raise regional culinary and regional cultures to attract visitors (travel.okezone.com).

So that research on experiential marketing applications with case studies on traditional unique markets is very interesting to do because it can provide information for companies to understand the importance of experiential marketing strategy applications which in turn can create loyal consumers (customers). Because experiences that are unique, interesting, and memorable will make consumers return to seek these things.

\section{LITERATURE REVIEW}

Experiential marketing is an effort used by companies or marketers to package products, so that they are able to offer emotional experiences to touch the hearts and feelings of consumers (Schmitt, 1999: 8). Meanwhile, Smilansky (2009:

5) states that experiential marketing is the process of identifying and satisfying profitable customer needs and aspirations, involving the use of two- way communication so as to give personality to the brand to be able to live and be added value to target customers.

Alma and Hurriyati (2008: 204) state that at the experiential marketing staAlma and Hurriyati (2008: 204) ge, the company views customers as someone who has emotional value, which is a view that emphasizes the relationship between the company and the customer because of a memorable experience by the customer. This unforgettable experience is what forms the basis for repeat purchases by customers or an indicator of loyalty.

Furthermore, Schmitt (1999: 26-29) argues that experiential marketing can be measured using five main factors, namely: Sense (sensory experience), Feel (affective), Think (creative cognitive experience), Act (Physical Experience and Entitle Lifestyle), and Relate (Social Identity Experience).

Sense experience is an effort to create experiences related to the five senses through sight, sound, touch, taste and smell. Where it is used to differentiate the company and its products in the market, motivate consumers to want to buy these products and convey value to consumers. Sense marketing is a way to touch the emotional side of consumers through experiences that consumers can get through the five senses (eyes, ears, tongue, skin and nose) that they have through products and services.

Feel experience is a feeling that arises through emotional experience. Feel marketing seeks to attract the deepest feelings and emotions of customers, with the aim of creating a customer experience from casual feelings to the intense emotional level of pride and prestige. Feel is a small concern that is directed to consumers with the aim of touching the customer's emotions in an extraordinary way. The purpose of feel experience is to move emotional stimuli (events, agents, objects) as part of feel strategies so that they can influence consumers' emotions and moods.

Think experience is a thought that arises based on experience. Think is a type of experience that aims to create cognitive, problem-solving problems that invite consumers to think creatively. There are several principles contained in think experience namely: 1) Surprise, which is an important basis in luring consumers to think creatively. Where suprise arises as a result if consumers feel that they get something more than what they want or expect so that satisfaction arises.

2) Intrigu, is thought that depends on the level of knowledge, things that attract consumers, or experiences that have previously been experienced by each individual. 3) Provocation, which creates a controversy or surprise, both pleasant and unpleasant.

Act experience is a marketing technique to create consumer experiences related to the physical body, behavior patterns and long-term lifestyle as well as experiences that occur from interactions with other people. Where the lifestyle itself is a pattern of individual behavior in life which is reflected in actions, interests and opinions. Act experience in the form of a lifestyle can be applied by using an ongoing trend or encouraging the creation of a new cultural trend. The purpose of act experience is to give an impression of behavior and lifestyle patterns, as well as to enrich social interaction patterns through the strategies implemented. Act marketing aims to create customers who can change their behavior and lifestyle.

Relate experience is a combination of the four aspects of experiential marketing, namely sense, feel, think, and act. In general, relate experience shows a relationship with other people, other groups (eg work, lifestyle) or a broader and abstract social community (eg country, society, culture). The purpose of relate experience is to connect these consumers with the culture and social environment that is reflected by a product's brand.

Kotler and Keller (2009: 138-139), state that satisfaction is the feeling of being happy or disappointed by someone that arises from comparing the perceived performance of the product (or results) against their expectations. If performance fails to meet expectations, customers will be dissatisfied. If the performance is as expected, the customer will be satisfied. If the performance exceeds expectations, the customer will be very satisfied or happy.

Araci, et al (2017) also explained that the dimensions that make up experiential marketing will be created in customers which will initially increase customer satisfaction and customer satisfaction will lead to positive behavioral intentions, namely repurchase intention. Furthermore, Hyunjin (2013) states that consumer satisfaction shows a positive direction 
between experiential marketing and the intention to visit again. Experiences that are applied using experiential marketing to visitors for the services they feel can create a good impression in the eyes of visitors that make visitors feel satisfied, so that visitors will be interested in making repeat visits which are a form of loyalty.

\section{RESEARCH METHOD}

This research is a descriptive qualitative research which is carried out to obtain certainty and describe the characteristics of the variables in a situation (Sekaran, 2000). This qualitative descriptive research was conducted using a case study approach. Yin (2003) argues that case studies are investigating contemporary phenomena in the context of real life, especially when the boundaries between phenomena and contexts are not very clear. Cooper and Schindler (2006) explain that in the case study researchers gather information from company profiles, annual reports, sales receipts, newspapers and magazines, which are accompanied by direct observation or combine it with data from interviews with participants.

The case study conducted in this research uses a holistic multiple-case design, and aims to identify the experiential marketing strategy implemented by Pasar Inis, Monggo Mampir Creative Market, and Pasar Menoreh in Purworejo.

This research uses the intrinsic case study and collective case study type because it aims to identify the experiential marketing strategies implemented by Inis Market, Monggo Mampir Creative Market, and Menoreh Market in Purworejo.

This study uses primary data in the form of observations and secondary data sourced from a company profile that is accessed by news that is accessed through magazine websites and daily newspapers; as well as other literature reviews, related to the experiential marketing strategy implemented by Inis Market, Monggo Mampir Creative Market, and Menoreh Market in Purworejo. The selection of these data sources is expected to create a fairly high internal validity of this case study.

The data collection method in this study was carried out by means of observation via the internet on information and news about the experiential marketing strategy implemented by Inis Market, Monggo Mampir Creative Market, and Menoreh Market in Purworejo.

Yin (2003) suggests three strategies that can be used to analyze data in case studies, namely: 1) Relying on the theoretical proposition, 2) Thinking about rival explanations, and 3) Developing a case description. The data obtained in this case study were analyzed by means of relying on theoretical propositions, namely basing the data and information obtained on theories related to experiential marketing strategies.

The research objects used in this case study are Inis Market, Monggo Mampir Creative Market, and Menoreh Market. Researchers determine these three markets as research objects because the three markets are proven to have high transparency and accountability, making it easier for researchers to access data and information, especially regarding market experiential marketing strategies through news through magazines and newspapers on the internet. In addition, researchers see that this market has a high commitment to implementing experiential marketing strategies as a form of their responsibility to consumers to provide pleasant and memorable services and experiences when consumers shop.

\section{RESULT AND DISCUSSION}

The traditional unique markets in Purworejo namely Inis Market, Monggo Mampir Creative Market, and Menoreh Market have applied experiential marketing strategies to attract and retain customers. All aspects of experiential marketing, be it sense, feel, think, act and relationship, have been applied by these markets to provide a pleasant experience and create an impression that touches the emotional side of market visitors. The result of this research show on table 1 and table 2 .

Table 1. Aspects and Forms of Experiential Marketing

\begin{tabular}{|l|l|}
\hline Sense & The five senses experince \\
\hline Feel & Emotional experince \\
\hline Think & The experience of think about value, quality, and creativity \\
\hline Act & The experience of behaviour and lifestyle changes \\
\hline Relate & $\begin{array}{l}\text { The experience to create related with culture and social } \\
\text { environment that reflected a brand }\end{array}$ \\
\hline
\end{tabular}

Source: Data Processed 2020 
Table 2. The Aplication of Experiential Marketing Strategy

\begin{tabular}{|c|c|c|c|}
\hline \multicolumn{2}{|c|}{ Experiential Marketing Aspecs } & \multicolumn{2}{|c|}{ Experiential Marketing Forms } \\
\hline $\begin{array}{c}\text { Experiential Marketing } \\
\text { / Market }\end{array}$ & Inis Market & $\begin{array}{l}\text { Monggo Mampir } \\
\text { Creative Market }\end{array}$ & Menoreh Market \\
\hline Sense & $\begin{array}{l}\text { Cleanlines s, the } \\
\text { beauty of the market, } \\
\text { the coolness of the } \\
\text { market, the distinctive } \\
\text { aroma of traditional } \\
\text { snacks in the market }\end{array}$ & $\begin{array}{l}\text { Cleanlines s, the } \\
\text { beauty of the market, } \\
\text { the coolness of the } \\
\text { market, the distinctive } \\
\text { aroma of traditional } \\
\text { snacks in the market }\end{array}$ & $\begin{array}{l}\text { Cleanlines s, the beauty } \\
\text { of the market, the } \\
\text { coolness of the market, } \\
\text { the distinctive aroma of } \\
\text { traditional snacks in the } \\
\text { market }\end{array}$ \\
\hline Feel & $\begin{array}{l}\text { Creating fun, pride } \\
\text { and positive mood } \\
\text { for visitors }\end{array}$ & $\begin{array}{l}\text { Creating fun, pride } \\
\text { and positive mood } \\
\text { for visitors }\end{array}$ & $\begin{array}{l}\text { Creating fun, pride and } \\
\text { positive mood for } \\
\text { visitors }\end{array}$ \\
\hline Think & $\begin{array}{l}\text { Visitors can think } \\
\text { about traditional } \\
\text { values that are } \\
\text { packaged in a } \\
\text { creative, contempor } \\
\text { ary, and quality } \\
\text { manner }\end{array}$ & $\begin{array}{l}\text { Visitors can think } \\
\text { about traditional } \\
\text { values that are } \\
\text { packaged in a } \\
\text { creative, contempor } \\
\text { ary, and quality } \\
\text { manner }\end{array}$ & $\begin{array}{l}\text { Visitors can think about } \\
\text { traditional values that are } \\
\text { packaged in a creative, } \\
\text { contempor ary, and } \\
\text { quality manner }\end{array}$ \\
\hline Act & $\begin{array}{l}\text { Visitors can be } \\
\text { inspired to live a } \\
\text { natural lifestyle and } \\
\text { behave in a more } \\
\text { intimate and familial } \\
\text { manner }\end{array}$ & $\begin{array}{l}\text { Visitors can be } \\
\text { inspired to live a } \\
\text { natural lifestyle and } \\
\text { behave in a more } \\
\text { intimate and familial } \\
\text { manner }\end{array}$ & $\begin{array}{l}\text { Visitors can be inspired } \\
\text { to live a natural lifestyle } \\
\text { and behave in a more } \\
\text { intimate and familial } \\
\text { manner }\end{array}$ \\
\hline Relate & $\begin{array}{l}\text { Visitors can understand } \\
\text { traditional clothes, } \\
\text { traditional games, } \\
\text { traditional culinary } \\
\text { delights, bamboo } \\
\text { currency, rural } \\
\text { communiti es }\end{array}$ & $\begin{array}{l}\text { Visitors can understand } \\
\text { traditional clothing, } \\
\text { punokawa n performan } \\
\text { ces, traditional culinary } \\
\text { delights, bamboo } \\
\text { currency, rural } \\
\text { communiti es }\end{array}$ & $\begin{array}{l}\text { Visitors can understand } \\
\text { traditional clothes, } \\
\text { traditional art performan } \\
\text { ces, traditional culinary } \\
\text { delights, bamboo } \\
\text { currency, rural } \\
\text { communities. }\end{array}$ \\
\hline
\end{tabular}

Source: Data Processed 2020

The application of this experiential marketing strategy can have a positive impact on the company to create a positive impression of a company in the minds of consumers. Researchers can then analyze the application of experiential marketing strategies in traditional markets in other areas or in other research objects such as restaurants, hotels or tourist villages, so that they can make an analysis of the experiential marketing phenomenon that is applied to different objects.

\section{CONCLUSION}

Based on the research results, the traditional unique markets in Purworejo namely Inis Market, Monggo Mampir Creative Market, and Menoreh Market have applied experiential marketing strategies to attract and retain customers. All aspects of experiential marketing, be it sense, feel, think, act and relationship, have been applied by these markets to provide a pleasant experience and create an impression that touches the emotional side of market visitors. This pleasant experience will certainly encourage visitors to come back to enjoy the attractive atmosphere in these markets.

\section{REFERENCES}

[1] Alma, Buchari dan Hurriyati Ratih. 2008. Manajemen Corporate Strategi Pemasaran Jasa Pendidikan: Fokus Pada Mutu dan Layanan Prima. Bandung: Alfabeta.

[2] Alma, Buchari. 2011. Management Pemasaran dan Pemasaran Jasa, Edisi Revisi. Bandung: Alfabeta.

[3] Araci, U. E., et. al. 2017. The Relation Among: Experiential Marketing, Customer Satisfaction, and Behavioral intention: a Study on Food and Beverage Business. 23rd International Scientific
Conference on Economic and Social Development: Book of Proceedings. 361-371.

[4] Assael, H.(2001), Consumer Behavior and Marketing Action, 6 th Ed., Cincinati, $\mathrm{OH}$ : South-Western College Publishing.

[5] Assael, H.(2004), Consumer Behavior and Marketing Action, 6 th Ed., Cincinati, OH : South-Western College Publishing.

[6] Cooper, D.R. and P.S. Schindler (2006), Business Research Methods, 9th ed., New York, NY: Irwin/McGraw-Hill.

[7] Hyunjin, Jeon. 2013. The Effect of Experiential Marketing on Customer Satisfaction and Revisit Intention of Beauty Salon Franchise Stores. Journal of Fashion Business, 17 (3), 109-121.

[8] Kotler, P. \& Keller, K. L. 2009. Marketing Management (13th Ed.). London: Pearson.

[9] Kartajaya, H.2010.Connect! Surving New Wave Marketing. Jakarta : Gramedia.

[10] Mothersbaugh, David. L. \& Hawkins, Del. I. 2016. Consumer Behavior, Building Marketing Strategy Thirteenth Edition. Mc Graw Hill Education: New York.

[11] Neuman, W. Lawrence (2000), Social Research Methods: Qualitative and Quantitative Approaches, 4th ed., London: Allyn and Bacon.

[12] Nigam, Ashutosh. 2012. Modeling Relationship between Experiential Marketing, Experiential Value and Purchase Intention in Organized Quick Service Chain Restaurants Using Structural Equation Modeling Approach. International Journal of Computer Science \& Management Studies (IJCSMS), 12. 114-123.

[13] Oyedele, A., et.al. 2018. Modeling Satisfaction and Repurchase Intentions of Mobile Smart Wristbands: The Role of Social Mindfulness and Perceived Value. Young Consumers.

[14] Sayre, Shay (2001), Qualitative Methods for Marketplace Research, Thousand Oaks, California: Sage Publication, Inc.

[15] Sekaran, Uma (2000), Research Methods for Business: A Skill Building 
Approach, 3rd ed., New York: John Wiley and Sons.

[16] Stake, R.E. (2000), "Case Study," dalam Denzin, N.K. and Yvonna S.L., (2nd ed), Handbook of Qualitative Research, Thousand Oaks, California: Sage Publication, Inc., pp. 435-454.

[17] Schmitt, B. (1999). Experiential Marketing: How To Get Your Customers To Sense, Feel, Think, Act, Relate To Your Company and Branda. New York: Freepass.

[18] Smilansky, S. 2009. Experiential Marketing : A Practical Guide To Interactive Brand Experiences. London: Koogan Page.
[19] Travel.okezon.com (Diakses 9 Desember 2020)

[20] Weiss, J.W. (2003), Business Ethics: A Stakeholder and Issues Management Approach, 3rd ed., Ohio: Thomson South- Western. Yin, R.K. (2003), Case Study Research: Design and Methods, 3rd ed., Thousand Oaks, California: Sage Publications, Inc.

[21] Yin, R.K. (2003), Case Study Research: Design and Methods, 3rd ed., Thousand Oaks, California: Sage Publications, Inc. www.antam.com, access on November 24th 2000 